\title{
The Politics of Assimilation
}

A Study of the French Jewish Community at the time of the Dreyfus Affair

\section{Michael R. Marrus}

This work investigates a difficult aspect of minority problems in a modern industrial state. By studying the beleaguered community of French Jews facing a storm of antiSemitic attack at the time of the Dreyfus Affair, it provides a chapter in the history of European Jewry before the Nazi holocaust, a revealing exploration of French history at the end of the nineteenth century, and a case study of assimilation as it operated upon a significant minority. 4 plates $£ 3.75$

\section{Charles James Fox and the Disinte- gration of the Whig Party 1782-1794}

\section{G. Mitchell}

This book sets out to examine how the intellectual and organizational bases of the Whig Party were developed under the leadership of Charles Fox. Special attention is paid to Fox's views on the crisis years of 1782-4 and on the changing circumstances in France between 1789 and 1794. On this evidence, an attempt is made to describe that set of ideas which could be called Foxite, and to indicate how far they continued to determine the thinking of the Whig party of the early nineteenth century. $\quad \mathfrak{f 3 . 7 5}$ Oxford Historical Monographs

\section{The Foreign Policy of Victorian England 1830-1902}

\section{Kenneth Bourne}

Dr Bourne introduces these documents, many of which were not easily accessible in print, with a long narrative survey of the period in which he analyses some of the prominent themes of his subject. This survey covers a very wide range of foreign policy from the Far and Middle East to America and Europe. $£ 3.75$ paper covers $£ 1.75$

\section{Enquiry Concerning Political Justice}

\section{William Godwin}

\section{Edited by K. Codell Carter}

William Godwin's Enquiry attempts to derive from utilitarianism answers to important questions on the proper relation between governmental authority and individual freedom. His approach and solutions deserve reconsideration today. This abridgement contains all that is of primary importance to the student of political philosophy. $£ 3.25$ paper covers $£ 1.60$

\section{Oxford University Press}

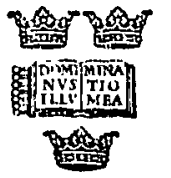




\title{
British Politics and European Unity
}

\author{
Parties, Elites and Pressure Groups
}

ROBERT J. LIEBER

Mr. Lieber analyses the context of policy-making in three distinct periods: 1956-60, the negotiations for the Free Trade Area and European Free Trade Association ; 1961-63, the Macmillan Government's unsuccessful effort to enter the Common Market; and 196667, the Wilson Government's renewal of the Common Market application.

He first treats the subject from the perspective of functional representation. Here he deals with the formation of sectional, or economic, pressure group attitudes and the methods with which these groups communicated their positions to governmental authorities in an effort to influence Britain's European policy.

\section{Employment Grievances and Disputes Procedures in Britain}

\author{
K. W. WEDDERBURN \& P. L. DAVIS
}

This comprehensive description of the formal and informal procedures for resolving grievances and trade disputes in Great Britain is the first attempt to look at the sociological background of British industrial relations from a legal point of view. It enables the student of industrial relations and labour law to evaluate the strengths and weaknesses of the system.

K.W. Wedderburn is Cassel Professor of Commercial Law at the University of London and P. L. Davis is Assistant Lecturer at the School of Law of the University of Warwick.

\section{University of California Press}

2-4 Brook Street, LONDON W1Y IAA

(ii) 


\title{
POLYARCHY
}

Participation and Opposition

ROBERT A. DAHL

Mr. Dahl identifies seven sets of conditions which he sees as favouring polyarchy-historical sequences; the socioeconomic order, both in form and level of development; inequalities; sub-cultures, cleavage patterns, and governmental effectiveness; the beliefs of political activites; and foreign control. He concludes with some tentative ideas on the implications of his analysis for strategies of change particularly as they might affect U.S. foreign policy. Jume 300 pages $f 3.95$

\section{THE HOUSE OF COMMONS, 1604-I610}

\section{WALLACE NOTESTEIN}

The basic issues characterizing the confrontations between James I and the Commons are examined, including the matters of royal prerogatives that were increasingly questioned by the Commons in the period 1604-1610. Mr. Notestein makes it clear that the Commons, following the age of Elizabeth, was consciously searching out a new sense of itself and its powets; neither James nor the House of Lords was able to appreciate fully the trends accompanying Commons' quest for a broadened role in national affairs. May 594 pages $£ 8.30$

\section{AFTER THE REVOLUTION?}

Authority in a Good Society

\section{ROBERT A. DAHL}

Drawing on his broad knowledge of political philosophy as well as democracy in action, Mr. Dahl guides his reader through a thoughtful examination of the principles on which the authority of democratic government rests, the question of who "the people" should be in the concept of "rule by the people", and the several different kinds of democracy that fit different situations. He concludes his analysis with a provocative discussion of ways in which we might handle there of the most pressing problems in American democracy; inequalities of various kinds, "the corporate leviathan", and the remoteness of government from the citizen. I 72 pages Cloth $£ 3.80$ Paper $\oint_{1}$.r.ro

\section{GOVERNMENT AND ECONOMIC DEVELOPMENT}

\section{Edited by GUSTAV RANIS}

The overall organization of the book covers major governmental functions-the government as goal setter, as producer, as regulator, and as fiscal agent-with a concluding section of comparative studies. All of the contributors have been associated with the Economic Growth Centre's programme of analysis of growth and structural change in 25 of the major developing countries, and the individual essays reflect the special expertise of each author in one or more geographical areas. une 608 pages $£ 8.30$

\author{
Yale University Press \\ 70 Great Russell St., WCI 3BY
}

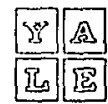




\title{
CIVIL DISOBEDIENCE
}

Conscience, Tactics, and the law

CARL COHEN Presents a general theory of civil disobedience-what it is, what kinds of it there are, how and when it might be justified. Special attention is given to the most frequently heard arguments in support of it: its connections with freedom of speech and -with the Nuremberg Judgments, its use as political tactic, and its concrete manifestation of conscientious principles. June 192 pages Cloth $£ 3.40$ Paper $£^{1.35}$

\section{EVERY WAR MUST END}

FRED CHARLES IKLÉ How are wars brought to an end? The origins of World War I and World War II have been studied frequently and in much detail; the motives, plans, and efforts for terminating these two wars have received far less consideration. August 192 pages Cloth S3.60 Paper $£ 1.35$

\section{CHINA AND RUSSIA: THE "GREAT GAME"}

O. EDMUND CLUBB The detailed inquiry into the largely unexplored field, with its particular emphasis on events since 1850 brings together in the book much information not conveniently available elsewhere. "It is a breathtakingly broad effort, successful beyond all reasonable expectations, and invaluable for the detail as well as insightful interrelationships it offers the reader with respect to time and spatial dimensions nowhere retated in so comprehensive and clear a fashion."-Allen S. Whiting, University of Michigan. Atrgust 475 pages illustrated $£ 4.95$

\section{SOVIET NATIONALITY PROBLEMS}

EDWARD ALLWORTH (Editor) The difficulties are analysed closely and their possible solutions are examined from both a contemporary and historical perspective. The authors scrutinize significant problems through the methodologies supplied by key academic disciplines. Research sources are discussed in a bibliographical section; maps and tables summarize census and other data about the nationalities. September 320 pages $£ 4.50$

\section{THE CZECHS UNDER NAZI RULE}

The Failure of National Resistance, 1939-1942

VOJTECH MASTNY Makes the first use of evidence from previously unknown captured German documents, will be of lasting interest to students of World War II and postwar history. May 272 pages $£_{4.50}$

\section{ORIGINS OF CHINESE MARXISM}

LI YU-NING A stimulating survey of the ways in which Western socialism was introduced into China at the beginning of the twentieth century. Of particular interest is the author's elucidation of the role of contemporancous Japanese thinking which entered China in the form of many translations of Japanese socialist writings July 96 pages Paper $f_{1} .80$

\author{
Columbia University Press \\ 70 Great Russell Street, London WCrB 3 BY
}




\section{THE AMERIGAN POLITICAL SGIENCE REVIEW and PS}

Institutional membership in the American Political Science Association offers subscribing members two journals, THE AMERICAN POLITICAL SCIENCE REVIEW and PS.

The REVIEW is the scholarly journal of the Association and includes articles covering comparative and American government, administration, public law, international relations, and political theory. An extensive book review section is also included.

PS is the Association's news journal with information on professional developments, research and study support, and professional as well as Association activities. Articles and reports on the discipline and profession are also included.

Annual Institutional Membership (includes subscription to two journals)

Domestic Institutions (Annually) $\$ 35.00$

Foreign Institutions $\$ 36.00$

\section{Full details of journals being}

published during 1971 are available in

the Cambridge Journals Catalogue,

available from the Journal Sales

Promotion departments of

Cambridge University Press

at either

200 EUSTON ROAD

LONDON NW1 2DB

32 EAST 57 th STREET

NEW YORK, N.Y. 10022

(v) 


\section{NOTES FOR CONTRIBUTORS}

I. All contributions should be sent to: The Editor, British Journal of Political Science, University of Essex, Colchester, Essex.

2. Articles submitted to the journal should in general be between 5,000 and 12,000 words long, though articles outside these limits will be acceptable if there is some good reason for their exceptional length or brevity. Articles in two or more parts may be accepted provided each part is independently intelligible.

3. Notes are welcome and every effort will be made to publish them quickly. A note should contain a body of original information, a new method for doing something or a new idea (speculation, argument, proof, etc.) presented in a brief and unadorned form without any inessential commentary. Only exceptionally will notes over two thousand words in length be accepted.

4. It is hoped to carry in each issue, where possible, an article of some 10,000 words reviewing the state of some area of the discipline. Review articles submitted without prior consultation will be considered, but in their own interest contributors would be well advised not to prepare a review article specially for the journal without first discussing the subject with the editor.

5. Letters, criticisms of articles, and similar contributions will be considered for early publication, especially if they are brief-say under 1,000 words.

6. Authors of articles and review articles receive twenty-five free offprints. Additional copies may be bought if ordered at proof stage.

7. Submission of an article is taken to imply that it has not previously been published, or is not being considered for publication elsewhere.

8. Contributions intended for publication should, if possible, be submitted IN DUPLICATE. They must be typed and reproduced in any clearly legible form. The preferred size of paper is $\mathbf{A}_{4}$ $\left(8 \frac{1}{4} \times 11 \frac{1}{2}\right.$ in) but quarto ( $8 \times 10$ in) or the US standard size $\left(8 \frac{1}{2} \times\right.$ I I in) will also be accepted.

9. The entire material, including quotations, footnotes, appendices, etc., should be double spaced with left-hand margins of at least $I_{2} \frac{1}{2}$ in. The preferred treatment of footnotes is that they should be numbered consecutively in the text and typed all together at the end, beginning on a fresh page, but manuscripts employing other methods of arranging footnotes will not be rejected simply on those grounds.

10. References to books and articles should include the following details: in the case of books, the full title, place of publication, publisher and date; in the case of articles, the title and author, full name of the journal, volume, year and page reference (first and last page). Good articles which contain this bibliographical information will be accepted, even if they do not follow the journal's own arrangement of the information.

I1. Anyone who is contemplating writing an article (etc.) for submission to the journal is urged to follow the style sheet issued by the journal, which covers a number of detailed points of spelling, punctuation, etc. Copies can be obtained by writing to the editor; in addition members of the board and the consultative committee can supply their colleagues with copies.

12. First proofs may be read and corrected by contributors provided that they can give the editor an address through which they can be reached without delay and can guarantee to return the corrected proofs to the editor, by airmail where appropriate, within ten days of receiving them. The master proof will always be sent direct to the editor by the printer; contributors will receive duplicates. 
B. J. Pol. S. 1, 2.

\title{
British Journal of Political Science
}

\author{
VOLUME 1 PART 2 APRIL 1971
}

ARTICLES

page

129 JOHN DEARLOVE

Councillors and interest groups in Kensington and Chelsea

155 GoRdon HaNdS

Roberto Michels and the study of political parties

173 Peter Frank

The CPSU Obkom First Secretary: A profile

191 ROBERT BOARDMAN

Conflict in Western perceptions of change: Two profiles of China

209 M. P. Masterson

On being unfair to Rawls, Rousseau and Williams or John Charvet and the incoherence of inequality

223 C. R. MitChELL

Foreign policy problems and polarized political communities: Some implications of a simple model

\section{NOTES}

253 W. P. GRANT

Local councils, conflict and 'Rules of the Game'

255 BRIAN BARRY

Conflict of interest and coalition formation

\section{CAMBRIDGE UNIVERSITY PRESS}

Bentley House, 200 Euston Road, London NWI 2DB

American Branch: 32 East 57th Street, New York, N.Y. 10022

Single parts $£ 2$ net in UK ( $\$ 6.00$ in USA)

Subscription price $£ 6$ net in UK ( $\$ 19.50$ in USA)

Printed in Great Britain by William Clowes \& Sons Limited, London, Colchester and Beccles 